\title{
AIR-LAYERING OF EASTERN WHITE PINE (Pinus strobus L.)
}

\author{
By J. L. FARRAR ${ }^{1}$ and W. D. MCJANNET ${ }^{2}$
}

\section{J. L. FARRAR}

John Farrar worked for the Canadian International Paper Company, Three Rivers Division, in 1936-37; and for the Forestry Branch at Ottawa from 1937 to 1956 (excluding four years' service with the R.C.A.F.). In 1956 he became Abitibi Professor of Forest Biology at the Faculty of Forestry, University of Toronto. He received his B.Sc.F. from the University of Toronto in 1936, his M.F. in 1939 and Ph.D. in 1955-both from Yale University. His work has been concerned with forest ecology.

\section{W. D. McJANNET}

William McJannet received his B.Sc.F. degree in 1954 from the Faculty of Forestry, University of Toronto. He was employed in the summer of 1951 with the Ontario-Minnesota Pulp and Paper Company, in the summer of 1952 with the Dominion Forestry Branch at Kananaskis, Alberta, and in the summer of 1953 with the Forest Resources Inventory of the Ontario Department of Lands and Forests. He joined the staff of the Forest Pathology Laboratory, Maple, Ontario, in 1954 and since that time has been employed on studies concerning blister rust and the ecology of ribes species. He is presently enrolled as a graduate student in the University of Toronto.

Layering is a method of vegetative propagation in which a branch is induced to grow roots before it is separated from the parent plant (Garner, 1944). Conditions favorable to rooting may be brought about by burying part of the branch in the ground. In air-layering, root formation is induced by wrapping a wad of moist material, such as sphagnum, around a branch and enclosing it with waterproof sheeting. The essential conditions seem to be abundant moisture, aeration, and lack of light. In addition, it is usual to remove a ring of bark because interference with the downward movement of substances in the phloem favors the initiation of roots.

Vegetative propagation is much used by tree breeders because plants produced in that way are genetically identical to the parent plant. Vegetative propagation permits an individual seedling to be multiplied and subjected to many tests before being grown for use. Under certain circumstances, propagation by layering may be preferred over the commoner methods using cuttings and grafts. Layering succeeds with species where cuttings root only with diffculty or not at all, because the branch is provided with water and other materials by the parent plant during the critical period when roots are developing. While the preparation of a layering requires more skill and effort than the preparation of a cutting, the subsequent care is simpler. Layerings need only be moistened at intervals of a week or more, whereas a bed of cuttings re-

\footnotetext{
${ }^{1}$ Abitibi Professor of Forest Biology, Faculty of Forestry, University of Toronto.

- Laboratory of Forest Pathology, Maple, Ontario, presently on educational leave attending the Faculty of Forestry, University of Toronto.

Received for publication March 4, 1958.
} 
quires constant attention to ensure that conditions of moisture and aeration are suitable.

A grafted scion grows on the roots of another plant. This prevents grafts from being used where some feature of root behavior is being tested. For such tests, layering provides plants growing on their own roots.

Mergen (1955 a and b) has been largely responsible for bringing airlayering to the attention of tree breeders in North America. He and his coworkers (Zak 1956, Hoekstra 1957) have achieved a high degree of success in air-layering certain southern pines. Since the white pine (Pinus strobus L.) is an important tree in eastern Canada, it was felt that it would be worthwhile to test Mergen's technique on this species. The writers are not aware of any previous report of the successful use of air-layering on white pine, though an example of natural layering in soil has been noted (Lutz, 1939).

The first experiment involved 96 plants. They were six years old and had been grown in a nursery at Glendon Hall, Toronto. They were potted in late October, 1956, brought into the greenhouse on December 23rd, and the layering procedure was begun during the next few days. All layerings were tried on the main stem on a part that had formed in 1954,1955 or 1956 ; most of them were on 1955 wood. The stem was girdled by removing a strip of bark about $1 / 4$-inch wide. Enough sphagnum was used to make a ball about 1 to 2 inches in diameter. Evaporation was restricted by a covering of polyethylene sheeting and aluminium foil.

Two chemicals, indoleacetic acid and indolebutyric acid, have been used with considerable success by Mergen and others to promote rooting, so treatments with these chemicals were incorporated into the investigation. They were applied in a dry mixture of powdered talc at concentrations ranging from 0.4 to $1.0 \%$. Some stems were treated with talc only, and some were left untreated. The powder was applied to the upper rim of the girdle.

Within two weeks it was observed that some stems were swelling just above the girdle and callus tissue was developing at the upper rim of the girdle. Seven weeks after girdling, the first roots were observed. After 14 weeks, data were recorded on the number of successfully rooted branches and the number of roots. At that time over $70 \%$ of the branches had developed one or more roots, and the average number of roots per successful layering was just over four. Most roots originated from the wound tissue at the upper rim of the girdle, but some originated a few millimeters further up the stem. The root tips were stout and brittle; the older parts were shrunken and tough (See Figure 1). No effects due to chemical treatment were demonstrated. Age of the wood at the position of the girdle did not seem to be an important factor.

The second experiment differed in that the experimental material consisted of fourteen wildings obtained at the University of Toronto Forest at Dorset, Ontario, and the plants were older-from 10 to 15 years of age. Only indolebutyric acid was tried; the concentration was $0.8 \%$. After 14 weeks $86 \%$ of the branches were rooted. No effects due to chemical treatment were observed. Bud elongation and root initiation were both delayed several weeks compared to the first experiment. The delay may have been due to the greater 
shock suffered by the larger plants at transplanting. However, it is known that branches strike root with increasing difficulty as the plant grows older (Garner, 1944).

One other point may be of interest. Mergen (1953a) noted that bud elongation was delayed on branches which developed roots. No such phenomenon was observed in the present experiment.

After the data were tallied, some branches were removed from the parent plant and potted. The roots developed well, as can be observed in the example shown in Figure 2.

This investigation indicated that air-layering can be successfully practiced on eastern white pine, at least up to the age of 15 years.

\section{REFERENCES}

1. GARNER, R. J. 1944. Propagation by cuttings and layers. Imp. Bur. Hort. and Plantation Crops, Tech. Com. No. 14. 79 pp.

2. HOEKSTRA, P. E. 1957. Air-layering of slash pine. For. Sci. 3:344-349.

3. LUTZ, H. J. 1939. Layering in eastern white pine. Bot. Gaz. 101:505-507.

4. MERGEN, F. 1955a. Air-layering of slash pine. J. For. 53:265-270.

5. MERGEN, F. 1955b. Vegetative propagation of slash pine. Southeastern For. Exp. Sta. Paper No. 54. 63 pp.

6. ZAK, B. 1956. Experimental air-layering of shortleaf and loblolly pine. Southeastern For. Exp. Sta. Paper No. 69. 12 pp. 